\title{
Recurrent Childhood Optic Nerve Glioma
}

National Cancer Institute

\section{Source}

National Cancer Institute. Recurrent Childhood Optic Nerve Glioma. NCI Thesaurus. Code C7531.

The reemergence of optic nerve glioma in childhood after a period of remission. 